\title{
HCV monoinfection and HIV/HCV coinfection enhance T-cell immune senescence in injecting drug users early during infection
}

\author{
Bart P. X. Grady ${ }^{1,2}$, Nening M. Nanlohy ${ }^{3}$ and Debbie van Baarle $3,4,5^{*}$
}

\begin{abstract}
Background: Injecting drug users (IDU) are at premature risk of developing multimorbidity and mortality from causes commonly observed in the elderly. Ageing of the immune system (immune-senescence) can lead to premature morbidity and mortality and can be accelerated by chronic viral infections. Here we investigated the impact of HCV monoinfection and HIV/HCV coinfection on immune parameters in (ex-) IDU. We analyzed telomere length and expression of activation, differentiation and exhaustion markers on $T$ cells at baseline $(t=1)$ and at follow-up ( $t=2)$ (median interval 16.9 years) in IDU who were: HCV mono-infected $(n=21)$; HIV/HCV coinfected $(n=23)$ or multiple exposed but uninfected (MEU) $(n=8)$.

Results: The median time interval between $t=1$ and $t=2$ was 16.9 years. Telomere length within $C D 4^{+}$and $C D 8^{+} T$ cells decreased significantly over time in all IDU groups ( $p \leq 0.012)$. CD4 ${ }^{+}$T-cell telomere length in HCV mono-infected IDU was significantly reduced compared to healthy donors at $t=1(p<0.008)$. HIV/HCV coinfected IDU had reduced $\mathrm{CD}^{+}$and $\mathrm{CD}^{+}$T-cell telomere lengths $(p \leq 0.002)$ to healthy donors $i$ at $t=1$. This was related to persistent levels of immune activation but not due to increased differentiation of T cells over time. Telomere length decrease was observed within all T-cell subsets, but mainly found in immature T cells $\left(\mathrm{CD} 27^{+} \mathrm{CD} 57^{+}\right)(p \leq 0.015)$.
\end{abstract}

Conclusions: HCV mono-infection and HIV/HCV coinfection enhance T-cell immune-senescence. Our data suggest that this occurred early during infection, which warrants early treatment for both HCV and HIV to reduce immune senescence in later life.

Keywords: Substance abuse, People who inject drugs, Frailty, Immunosenescence, Longitudinal

\section{Background}

As people age, the immune system exhibits ageassociated changes resulting in impaired immunity. This so-called immune senescence is a complex multifactorial phenomenon characterized by a number of features including: i) reduced number of naïve T cells; ii) increased frequencies of differentiated $\mathrm{CD} 28^{-} \mathrm{CD} 57^{+}$ $\mathrm{T}$ cells that have a reduced proliferative capacity; iii) reduced $\mathrm{CD} 4 / \mathrm{CD} 8$ ratio; oligoclonal expansion of $\mathrm{CD} 8$

\footnotetext{
* Correspondence: Debbie.van.baarle@rivm.nl

${ }^{3}$ Department of Immunology, University Medical Center Utrecht, Utrecht, The Netherlands

${ }^{4}$ Department of Internal Medicine, University Medical Center Utrecht, Utrecht, The Netherlands

Full list of author information is available at the end of the article
}

$\mathrm{T}$ cells, and iv) progressive shortening of telomeres [1-3]. Telomeres are repetitive (TTAGGG) $)_{\mathrm{n}}$ nucleotide sequences that shorten with each cell division [4]. Among people aged over 60 years, short leukocyte telomere length has been associated with higher mortality rates from infectious diseases [5].

People who inject drugs (injecting drug users, IDU) are at increased risk of contracting both acute and chronic infections [6, 7]. The prevalence of $\mathrm{HCV}$ antibodies in IDU ranges from $15-98 \%[8,9]$. Upon $\mathrm{HCV}$ infection, $75 \%$ of individuals progress to chronic infection and are at risk for progressive liver disease, liver cirrhosis and hepatocellular carcinoma [10]. The worldwide prevalence of HIV infection among IDU is 
estimated to be $18 \%$ [11]. With the advent of combination antiretroviral therapy (cART) and decline in drug-related causes of death, the mean age of IDU is increasing $[12,13]$ and IDU are at premature risk of developing multimorbidity and mortality from causes commonly observed in the elderly $[14,15]$.

Immunological changes and increased levels of inflammation could form the basis of this premature burden of morbidity and mortality among ageing DU. Progression of immune senescence was shown to be accelerated by chronic viral infections such as HIV through (long-term) continuous immune activation [16, 17]. Despite adequate combination antiretroviral therapy (cART), HIV infected individuals have increased risk for non-AIDS morbidity as compared to age-matched controls $[18,19]$. There is a growing body of literature that suggests that $\mathrm{HCV}$ has a role in extrahepatic morbidity and mortality likely through a similar mechanism of immune activation [20, 21]. Indeed, like HIV, HCV infection also leads to PD- $1^{\text {high }}$ and TIM- $3^{\text {high }} \mathrm{T}$ cells, a phenotype associated with exhaustion due to persistent antigenic pressure [22]. In addition to $\mathrm{HIV}$ and $\mathrm{HCV}$ monoinfection, $\mathrm{HIV} / \mathrm{HCV}$ coinfected individuals do not only seem to have increased risk for liver disease progression [23] but also progression to AIDS [24], which suggests that both viruses could enhance each other's disease progression [25].

To assess the impact of an infection with $\mathrm{HCV}$ and $\mathrm{HIV} / \mathrm{HCV}$ specifically, we studied parameters associated with immune senescence. To this end, we included IDU with HCV mono- or HIV/HCV coinfection. As a control group to control for use of cocaine, opioid and social practices connected with drug use, we studied IDU with similar injecting risk behavior that where multiple exposed but uninfected (MEU) from the Amsterdam Cohort Studies (ACS) among drug users, at two time-points during follow-up $>15$ years apart. To address the severity of immune senescence parameters, we compared these between the specific IDU groups and healthy individuals.

\section{Results}

\section{Study population}

We included $23 \mathrm{HIV} / \mathrm{HCV}$ coinfected, $21 \mathrm{HCV}$ infected and 8 MEU DU (Table 1) who all injected

Table 1 Baseline and follow-up characteristics of the study population

\begin{tabular}{|c|c|c|c|c|c|}
\hline & HD\# & MEU & $\mathrm{HCV}$ & $\mathrm{HIV} / \mathrm{HCV}$ & $P$-value \\
\hline Number & 22 & 8 & 21 & 23 & \\
\hline \multicolumn{6}{|l|}{ General characteristics } \\
\hline Gender, n male (\%) & * & $7(87.5)$ & $15(71.4)$ & $14(60.9)$ & 0.36 \\
\hline Western ethnicity, n (\%) & * & $8(100.0)$ & $21(100.0)$ & 19 (82.6) & 0.13 \\
\hline Ever injected drugs, n (\%) & $*$ & $8(100.0)$ & $21(100.0)$ & $23(100.0)$ & 1.00 \\
\hline Years of injecting (IQR) & * & $6.7(6.1-13.6)$ & $13.4(5.4-19.6)$ & $9.0(6.4-14.6)$ & 0.20 \\
\hline \multicolumn{6}{|l|}{ Baseline $(T=1)$} \\
\hline Age, median (IQR) & $36.4(31.5-40.1)$ & $32.8(28.7-35.2)$ & $34.4(30.7-37.5)$ & $35.2(32.6-39.8)$ & 0.30 \\
\hline $\begin{array}{l}\text { Sample since study entry } \\
\text { (months), median (IQR) }\end{array}$ & * & $12.7(0-47.6)$ & $12.6(1.7-31.7)$ & $14.7(0-25.8)$ & 0.98 \\
\hline $\begin{array}{l}\text { Year of sample, } \\
\text { median (IQR) }\end{array}$ & * & 1992 (1989-1994) & 1992 (1990-1994) & 1991 (1989-1993) & 0.43 \\
\hline Injecting past 6 months(\%) & * & $1(12.5)$ & $14(66.7)$ & $16(73.9)$ & 0.07 \\
\hline $\begin{array}{l}\text { CD } 4 \text { cell counts } 10^{6} \text { cells/L, } \\
\text { median (IQR) }\end{array}$ & * & * & * & $590(470-742)$ & $*$ \\
\hline cART, n (\%) & * & * & * & $1(4.5)$ & * \\
\hline \multicolumn{6}{|l|}{ Follow-up $(T=2)$} \\
\hline Age, median (IQR) & $52.7(48.3-57.6)$ & $51.7(49.2-54.8)$ & $51.7(47.4-55.5)$ & $50.4(47.7-54.2)$ & 0.97 \\
\hline Injecting past 6 months (\%) & * & $1(12.5)$ & $4(19.0)$ & $4(17.9)$ & 0.92 \\
\hline $\begin{array}{l}\text { CD } 4 \text { cell counts } 10^{6} \text { cells/L, } \\
\text { median (IQR) }\end{array}$ & * & * & * & $341(233-663)$ & * \\
\hline cART, n (\%) & * & * & * & $20(87.0)$ & * \\
\hline Years on cART, median (IQR) & * & * & * & $7.1(2.1-10.7)$ & * \\
\hline
\end{tabular}


drugs for at least 2 years. The number of years of injecting risk behavior was comparable between groups, although MEU IDU reported less injecting in the past 6 months prior to the baseline time point $(p=0.07)$. At baseline, 1 out of $23(4.5 \%) \mathrm{HIV} / \mathrm{HCV}$ IDU was on combination antiretroviral therapy (cART) and this number increased to 20 out of 23 (87.0 \%) at follow-up. The remaining three HIV/ $\mathrm{HCV}$ cases never received cART. For those who received cART the median time since start cART was 7.1 years (IQR 2.1-10.7). Median nadir CD4 count was 130 cells $/ \mathrm{mm}^{3}$ (IQR 90-210).

\section{Flowcytometric analyses of telomere length}

Using flow-FISH, telomere length can be measured in distinct cell populations without prior cell sorts [26]. Here we extended the flow-FISH protocol $[27,28]$ to a 5 color- flow-FISH (incorporating the phenotypic markers CD3, CD8, CD27 and CD57) enabling us to investigate CD4 and CD8 phenotypic T cell subsets in one sample. The assay has been shown to be sensitive enough to detect significant decreases in telomere length [28].

During ageing the relative telomere length (RTL) decreases, as shown in Fig. 1a in $\mathrm{CD}^{+} \mathrm{T}$ cells over a period of 17 years. Using CD27/CD57 expression for

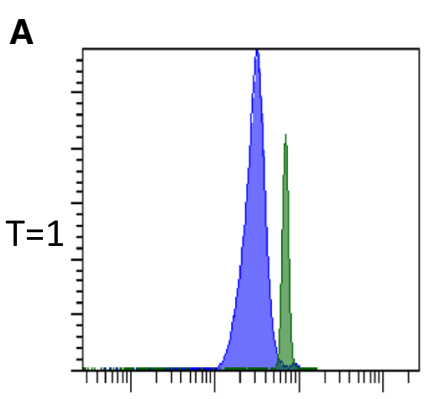

Telomere

B

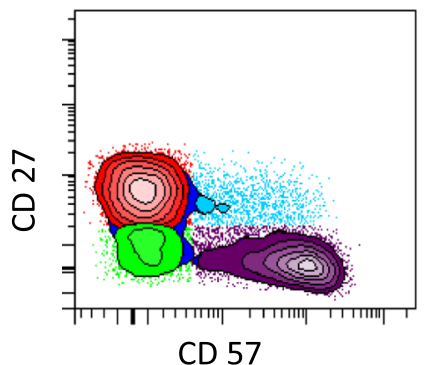

C $\quad \mathrm{CD} 4$ cells

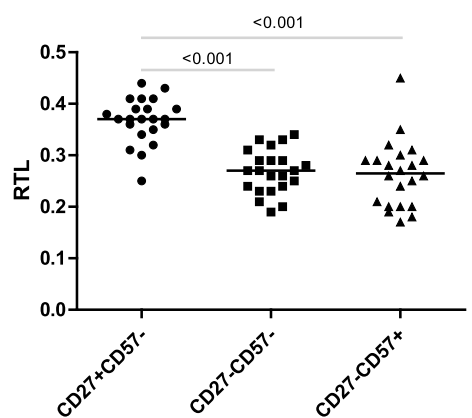

$\mathrm{T}=2$

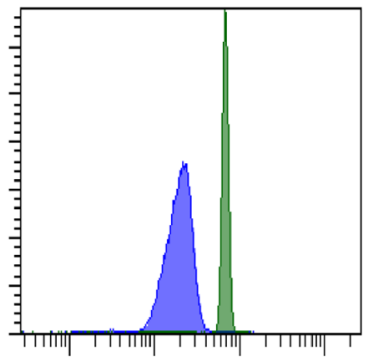

Telomere

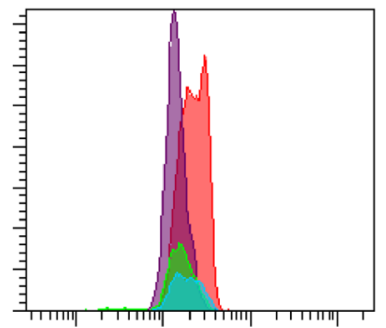

Telomere

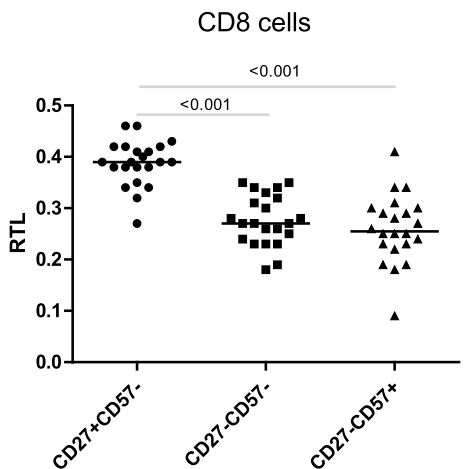

Fig. 1 Flowcytometric analysis of telomere length within T-cell subsets. a Representative histograms of CD8+ telomere length (blue) and calf thymocytes (green) at the baseline timepoint $(\mathrm{t}=1)$ and a follow-up timepoint more than 15 years later $(\mathrm{t}=2)$. $\mathbf{b}$ Telomere length analysis (or relative Telomere lengths) within T-cell subsets defined by CD27 and CD57-expression (left panel) as CD27 ${ }^{+}$CD57 (red), CD27 CD57 (green) and $\mathrm{CD}^{\circ} \mathrm{CD}^{-} 7^{+}$(purple). $\mathbf{c}$ Differences in relative telomere length (RTL) in healthy donors between immature $\left(\mathrm{CD} 27^{+} \mathrm{CD} 57^{\circ}\right)$, mature $\left(\mathrm{CD} 27^{-} \mathrm{CD} 57^{-}\right)$ and mature differentiated $\left(\mathrm{CD} 27^{-} \mathrm{CD} 57^{+}\right) \mathrm{T}$ cells stratified for CD4 (left panel) and CD8 T cells (right panel). The black lines represent median values. Statistical analyses were performed using Kruskal-Wallis and post hoc Mann-Whitney $U$ test, a two sided $p$-value $<0.05$ was considered statistically significant 
defining immature $\left(\mathrm{CD} 27^{+} \mathrm{CD} 57^{-}\right)$, mature $\left(\mathrm{CD} 27^{-} \mathrm{CD} 57^{-}\right.$ ) and mature differentiated $\left(\mathrm{CD} 27^{-} \mathrm{CD} 57^{+}\right)$phenotypes [29, 30] (Fig. 1b), we were also able to show differences in telomere length between these subsets (Fig. 1c). In both $\mathrm{CD} 4^{+}$and $\mathrm{CD} 8^{+} \mathrm{T}$ cells, immature cells had significantly longer RTL compared to mature and mature differentiated cells $(p<0.001)$. Shortened telomeres have been associated with CD57 expression on the surface of T-cells [31]. Here we show that loss of CD27 expression is already associated with reduced RTL in $\mathrm{CD}^{+}$and $\mathrm{CD}^{+} \mathrm{T}$ cells. Mature and mature differentiated cells have similar RTL, indicating that they have undergone comparable rounds of proliferation (Fig. 1c).

Telomere length decreases over time in $\mathrm{CD}^{+}$and $\mathrm{CD}^{+} \mathrm{T}$ cells and is mostly affected by HIV/HCV coinfection

We investigated whether there was a decrease in RTL among $\mathrm{CD}_{4}^{+}$and $\mathrm{CD}^{+} \mathrm{T}$ cells over time (Fig. 2a). The RTL of CD4 ${ }^{+}$T cells decreased significantly over time in all IDU groups $(p \leq 0.012)$. An impact at baseline of $\mathrm{HCV}$ monoinfection and $\mathrm{HIV} / \mathrm{HCV}$ coinfection was observed among the RTL in $\mathrm{CD} 4^{+} \mathrm{T}$ cells compared to healthy donors $(p=0.008$ and $p=0.002$ respectively). Among $\mathrm{CD}^{+}{ }^{+}$cells the RTL also decreased in all IDU groups $(p \leq 0.017)$. The median RTL of $\mathrm{CD}^{+} \mathrm{T}$ cells from HIV/HCV coinfected IDU at baseline was significantly lower than in healthy donors $(p=0.0015)$ and comparable to the median RTL of healthy donors, $\mathrm{HCV}$ and MEU at follow-up $(\mathrm{T}=2)$. In a sensitivity analysis, using a linear regression model with age included as a fixed variable, we demonstrated that the observed difference as mentioned above were independent of age (Additional file 1: Table S1). To analyse the decline in RTL per individual, the 10 year RTL decline was calculated. With increasing age, the RTL decline rate did not statistically differ between the study groups (Fig. 2b). Taken together, these results suggest The effect of these infections occurred before the first time point of the study of $\mathrm{HIV} / \mathrm{HCV}$ coinfection on immune senescence.

Lower telomere lengths in immature T cells in HIV/HCV coinfected IDU coincides with increased numbers of differentiated cells

Persistent antigenic stimulation leads to linear differentiation of naïve cells losing CD27 [32, 33] and gradually gaining CD57 [30], resulting in a decreased capacity to proliferate [34]. Therefore long-term effects of persistent antigenic stimulation could be reflected in the percentage

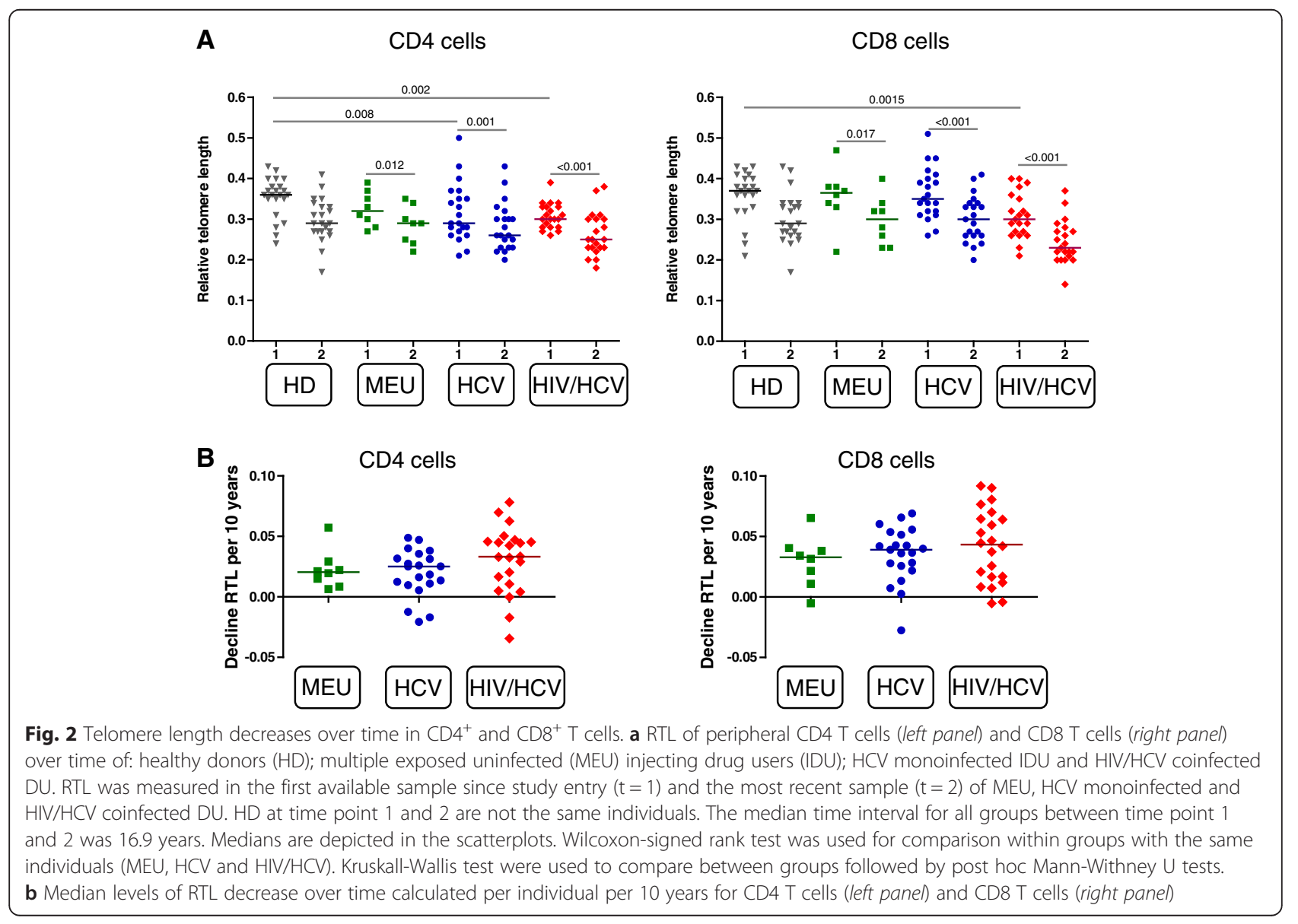


of immature, mature and mature differentiated T-cell subsets. As shown in Fig. 3a the proportion of immature $\mathrm{CD}^{+}$and $\mathrm{CD}^{+} \mathrm{T}$ cells was significantly lower among $\mathrm{HIV} / \mathrm{HCV}$ coinfected IDU than healthy donors at both baseline and follow-upt $(p<0.01)$ (Fig. 3c) fitting with the lower telomere lengths in this patient group. However, we did not observe a significant increase in the percentage of differentiation over time within each of the study groups, indicating that loss of telomere length over time is not simply due to increased T-cell differentiation. Even more, the RTL significantly decreased over time in all T-cell subsets for all IDU groups ( $\leq 0.027$, Fig. $3 b$ and $c)$. In addition, in immature $\mathrm{CD} 8^{+} \mathrm{T}$ cells, the RTL in $\mathrm{HIV} / \mathrm{HCV}$ infected IDU was significantly lower compared to healthy donors $(p=0.015)$. The $\mathrm{CD} 27^{+} \mathrm{CD} 57^{-}$immature $\mathrm{CD} 4^{+} \mathrm{T}$ cells from young IDU with $\mathrm{HCV}$ or $\mathrm{HIV} / \mathrm{HCV}$ also had a lower RTL than healthy donors $(p=0.056$ and $p<0.001$ respectively). Thus, the decrease in telomere length over time does not seem to be due to enhanced differentiation of $\mathrm{T}$ cells, but affects all T-cell subsets.

\section{Increased levels of activation and exhaustion in peripheral T cells of HCV monoinfected and HIV/HCV coinfected DU}

To investigate whether the observed decrease in RTL over time could be due to enhanced immune activation, we analyzed the expression of HLA-DR and CD38 on T cells. IDU with HIV/HCV coinfection had a significantly higher frequency of $\mathrm{CD}^{+}$and $\mathrm{CD} 8^{+}$T-cell activation $\left(\mathrm{HLADR}^{+} \mathrm{CD} 38^{+}\right)$compared to healthy donors at both baseline and follow-up $(p<0.004$, Fig. 4). IDU with HCV monoinfection had higher levels of $\mathrm{CD}^{+} \mathrm{T}$ cell activation at baseline compared to healthy donors $(p<0.001)$, but this effect diminished over time. The level of $\mathrm{CD} 4^{+}$ and $\mathrm{CD}^{+} \mathrm{T}$ cell activation declined over time in $\mathrm{HIV} /$ HCV infected DU, but was still higher than in healthy donors $(p<0.001)$. The expression of activation markers was also significantly higher in $\mathrm{HCV}$ and $\mathrm{HIV} / \mathrm{HCV}$ infected IDU compared to MEU DU. Interestingly, young MEU IDU were comparable to young healthy donors with respect to immune activation, which suggests there was no impact of drug use or social practices on immune activation. However, the levels of CD38 and HLA-DR among MEU IDU remained stable over time, suggesting that MEU IDU may actively suppress immune activation.

Persistent antigen exposure does not only lead to a rapid turnover and telomere erosion but can also lead to a subset of $\mathrm{T}$ cells that become functionally exhausted. To investigate whether T-cell exhaustion is upregulated by HIV and/or HCV we evaluated programmed death factor 1 (PD-1) expression levels, shown to be marker of exhaustion in chronic viral diseases but increasingly also considered as activation marker after acute infection (to control T-cell activity). At baseline both $\mathrm{CD} 4^{+}$and $\mathrm{CD} 8^{+}$ $\mathrm{T}$ cells of $\mathrm{HIV} / \mathrm{HCV}$ infected IDU expressed higher levels of PD-1 than healthy donors. Over time, the CD8 PD-1 expression of HIV/HCV infected IDU declined significantly $(p=0.014)$ to a level comparable to healthy donors, most likely due to cART. Among HCV monoinfected IDU the expression of PD- 1 in $\mathrm{CD} 4^{+} \mathrm{T}$ cells was higher compared to healthy donors $(p=0.023)$. Even though PD-1 expression in these cells significantly increased over time $(p=0.005)$ the expression level was comparable to older healthy donors, MEU and HIV/ HCV coinfected DU. Thus HIV/HCV coinfection leads to both general increased immune activation and increased PD-1 expression.

\section{Methods}

Study population

Study subjects were recruited from the ACS among DU, an open, prospective cohort study to investigate the prevalence, incidence, and risk factors of HIV infections and other blood-borne diseases [35]. Enrollment is voluntary, anonymous, and written informed consent is obtained from each participant at the intake visit. The medical ethics committee of the Academic Medical Center approved this observational study. Blood is drawn each visit for laboratory testing and storage of peripheral blood mononuclear cells (PBMC) and serum. HIV testing and HCV testing have been described before [36]. In short, all participants were prospectively tested for HIV antibodies and were confirmed by Western blot. Chronic HCV infection was defined by the presence of positive anti-HCV tests and the presence of HCV RNA at multiple time-points during follow up, without evidence for spontaneous clearance of HCV. None of $\mathrm{HCV}$-infected participants received $\mathrm{HCV}$-treatment.

For this study we included three groups of DU, namely: IDU who had an HIV/HCV coinfection $(n=23)$, IDU who had a chronic HCV infection $(n=21)$ and as a control for a drug using career IDU who were multiple exposed but uninfected (MEU) $(n=8)$ (Table 1). Subjects were included if they had an injecting drug use career greater than 2 years, were aged between 43 and 60 years and had PBMCs available. In addition to these follow-up samples we also included the first available PBMCs sample since study entry in the ACS for each subject. Unfortunately we were unable to include healthy donors with stored PBMC over the same time period. Therefore, to compare the study groups to healthy donors we recruited 2 groups of anonymous healthy donors from the blood bank, one aged between 43-60 years and one aged between 2343 years, in order to match the ages of our study groups. In order to donate blood, voluntary participating individuals are tested for $\mathrm{HIV}, \mathrm{HBV}, \mathrm{HCV}$ and 


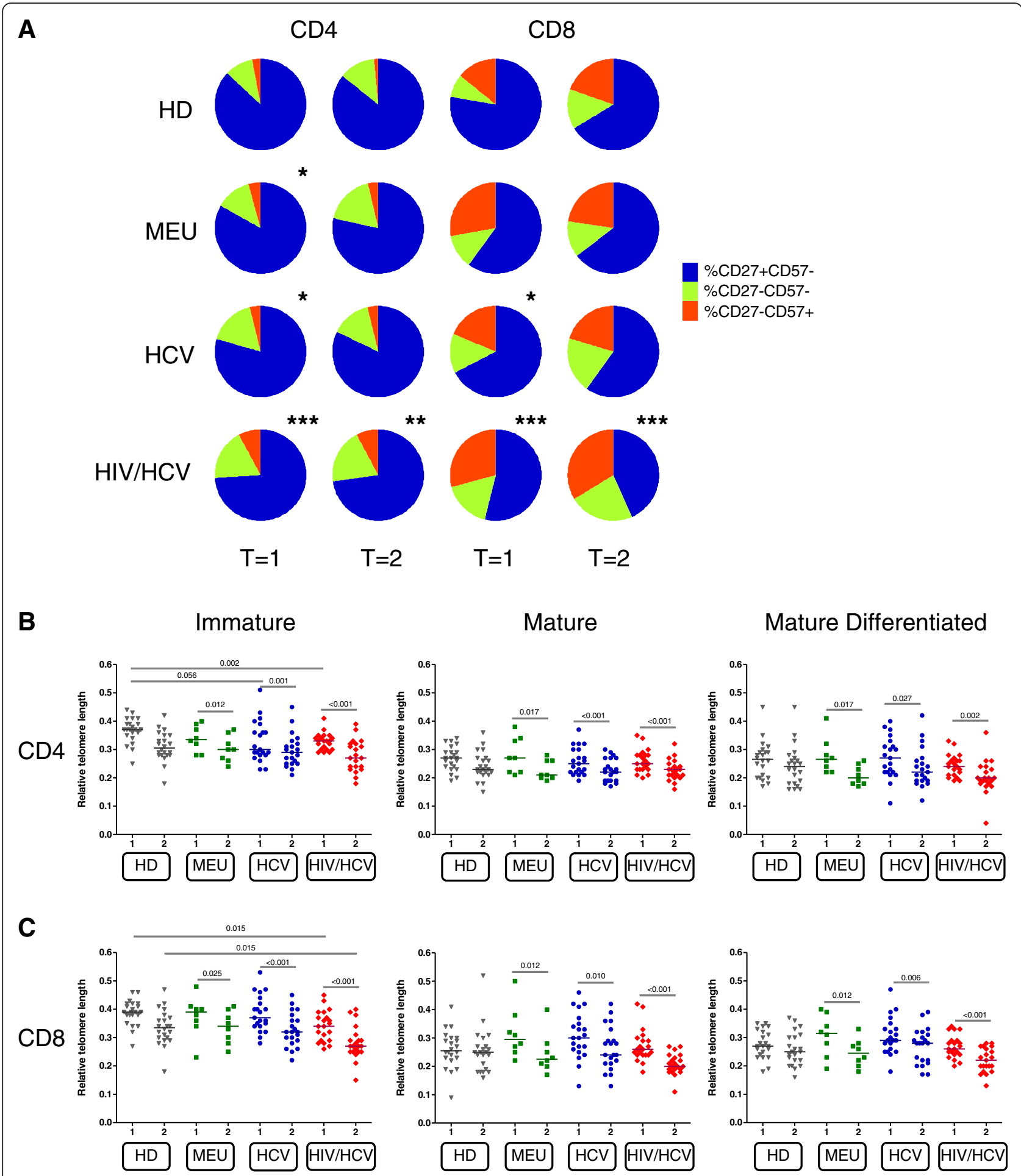

Fig. 3 (See legend on next page.) 
(See figure on previous page.)

Fig. 3 No enhanced T-cell differentiation in time and lower relative telomere lengths (RTL) in immature $C D 4^{+}$and $C D 8^{+} T$ cells. a Pie charts of normalised median frequencies of immature (blue), mature (green) and mature differentiated (red) $\mathrm{CD} 4^{+}$(left panels) and CD8 ${ }^{+} \mathrm{T}$ cells (right panels). Frequencies of immature cells were compared with $\mathrm{HD}$ for $\mathrm{CD} 4^{+}$and $\mathrm{CD} 8^{+} \mathrm{T}$ cells for time-point 1 and for time-point 2. $P$-values were calculated using the Mann- Whitney $U$ test. ${ }^{*} p<0.05 ;{ }^{*} p<0.01 ;{ }^{* * *}<0.001$. b Relative telomere length (RTL) of peripheral CD4 T cell subsets (b) and CD8 T cell subsets (c) of: healthy donors (HD); multiple exposed uninfected (MEU) drug users (DU); HCV monoinfected IDU and HIV/HCV coinfected DU. RTL was measured in the first available sample since study entry $(t=1)$ and the most recent sample $(t=2)$ of MEU, HCV monoinfected and HIV/HCV coinfected DU. Subsets are depicted as follows: immature (CD27 ${ }^{+}$CD57), mature (CD27 CD57) and mature differentiated $\left(\mathrm{CD} 2 \mathrm{CD}^{\mathrm{C}} 7^{+}\right)$. $\mathrm{HD}$ at time point 1 and 2 are not the same individuals. The median time interval for all groups between time point 1 and 2 was 16.9 years. Medians are depicted in the plots. Wilcoxon-signed rank test was used for comparison within groups with the same individuals (MEU, HCV and $\mathrm{HIV} / \mathrm{HCV}$. Kruskall-Wallis test were used to compare between groups followed by post hoc Mann-Withney $U$ tests

HEV. The blood bank actively screens for IDU and men who have sex with men or a history of IDU or men who have sex with men. These individuals were excluded from blood donation.

\section{PBMC storage}

From all study participants, PBMCs were isolated from heparinized blood using a Ficoll-Hypaque density gradient centrifugation and cryopreserved using a computerized freezing system in liquid nitrogen within $24 \mathrm{~h}$ of collection.

\section{Flow cytometric analyses}

Stored PBMCs were rapidly thawed and $1^{*} 10^{6}$ cells were stained in PBS with $0.5 \%$ bovine serum albumin (BSA) and $0.1 \%$ sodium azide using combinations of the following antibodies: CD4 Pacific Blue, CD3 AlexaFluor700, HLA-DR PerCP (Biolegend), CD8 Horizon V500, CD27 APC-eFluor780 (eBioscience), CD38 PE (Caltag) and PD1 PerCP-Cy5.5. Cells were incubated with the antibodies for $20 \mathrm{~min}$ at $4{ }^{\circ} \mathrm{C}$. After washing with $\mathrm{PBS} / 0.5 \% \mathrm{BSA}$, cells were fixed with Cellfix (BD) and directly analyzed by flow cytometry. For each sample a minimum of 100,000
A

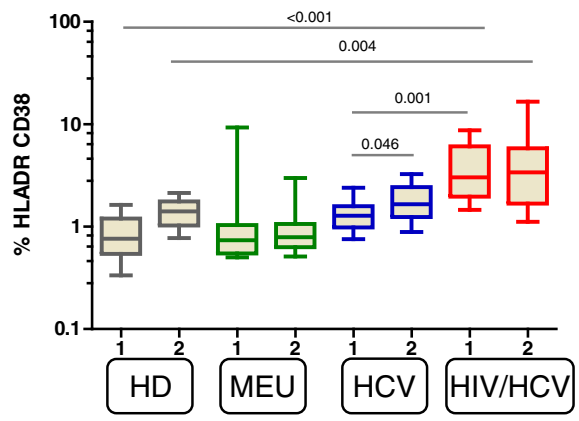

B

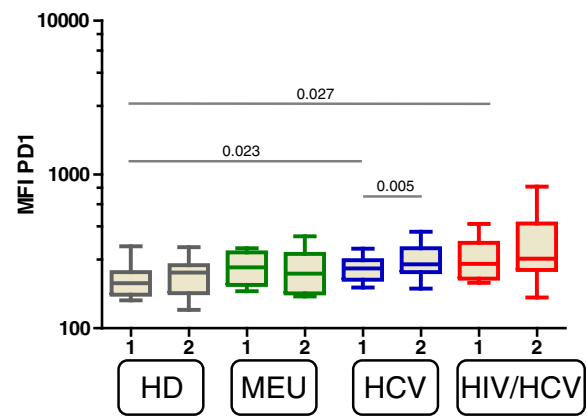

CD8

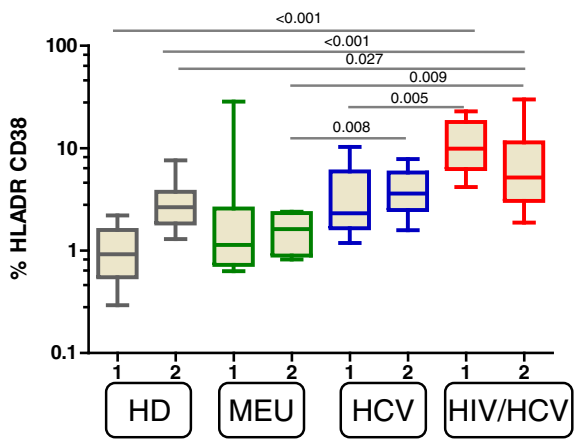

CD8

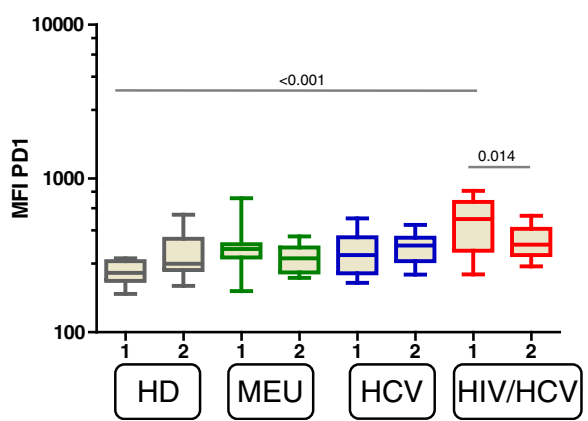

Fig. 4 Levels of immune activation and exhaustion are increased in HCV/HIV coinfected injecting drug users (IDU). Percentages of HLA-DR/CD38 positive peripheral CD4 ${ }^{+} T$ cells and $C D 8^{+} T$ cells (a) of: healthy donors (HD); MEU IDU; HCV monoinfected IDU and HIV/HCV coinfected DU. RTL was measured in the first available sample since study entry $(\mathrm{t}=2)$ and the most recent sample $(\mathrm{t}=2)$ of MEU, HCV monoinfected and HIV/HCV coinfected DU. b Median fluorescent intensity (MFI) of PD1 in peripheral CD4 ${ }^{+} \mathrm{T}$ cells and $\mathrm{CD} 8^{+} \mathrm{T}$ cells. Box and whisker plots show the median and 10-90 percentiles. The Wilcoxon-signed rank test was used for comparison within groups with the same individuals (MEU, HCV and HIV/HCV). Kruskall-Wallis test were used to compare between groups followed by post hoc Mann-Withney U tests 
cells were acquired using a LSRII FACS (BD) and data were processed using FACSDiva 6.0 software (BD).

\section{Flowcytometric analysis of telomere length in T cell subsets}

Telomere length of PBMCs was assessed using a five color flow cytometry fluorescent in situ hybridization (flow-FISH) protocol, adapted from Baerlocher et al. [27] Here, telomeres are hybridized to an AlexaFluor488 labeled peptide nucleic acid (PNA) telomeric (C3TA2) ${ }^{3}$ probe and subsequently analyzed by flow cytometry. In short, stored PBMCs were rapidly thawed and $2^{*} 10^{6}$ cells were stained with heat-stable fluorochrome-labeled antibodies for CD3 Pacific Blue (eBioscience), CD8 V500 (BD), CD27 Alexa fluor 647 (BD) and CD57-biotin (Biolegend), followed by streptavidin-Cy3 (Sigma). After washing, the cells were fixed with bis(sulfosuccinimidyl)suberate $\left(\mathrm{BS}^{3}\right.$, Pierce) for $30 \mathrm{~min}$ at $4{ }^{\circ} \mathrm{C}$ in the dark. Cells were washed with PBS and incubated for $10 \mathrm{~min}$ with an hybridization solution, with and without the PNA probe and 15 min at $82{ }^{\circ} \mathrm{C}$ to denature the DNA. After $1 \mathrm{~h}$ of hybridization at room temperature and in the dark, cells were washed and analyzed immediately by flow cytometry. Samples were gated on live, singlet CD3 ${ }^{+} \mathrm{T}$ cells. Calf thymocytes were included in each experiment as an internal control. The gating strategy is shown in Additional file 2: Figure S1. Relative telomere length (RTL) of each sample was calculated as the ratio between the median fluorescent intensity (MFI) of the T cell subset of interest with probe (minus the MFI without probe) divided by the MFI of the calf thymocytes with probe (minus the MFI without probe). All experiments were performed in duplo and RTLs were averaged per sample.

\section{Statistical analyses}

To test for statistical significance between groups we used the Kruskall-Wallis test and if significant followed by post-hoc Mann-Whitney $U$ test. Comparisons within groups (related samples) were made using the paired Wilcoxon signed rank test, otherwise the Mann-Whitney $U$ test was used. A two sided $p$-value $<0.05$ was considered statistically significant. To investigate whether the decline in RTL could be confounded by age we performed a sensitivity analysis using a linear regression model with age as a fixed variable. All analyses were performed using SPSS (version 20.0; SPSS Inc.) statistical software. Graphs were made using Graphpad (version 6.1; GraphPad Software, Inc.)

\section{Discussion}

In this longitudinal study we observed significantly decreased telomere lengths among ageing $\mathrm{HIV} / \mathrm{HCV}$ coinfected IDU as compared to healthy donors. In the period in which IDU had no access to cART, the impact of $\mathrm{HIV} / \mathrm{HCV}$ on telomere length was noticeable already at the first timepoint in infection that we analysed, in both the CD4 and CD8 T-cell compartment with significantly reduced telomere lengths. During a period of 16 years we observed no increased decline of telomere length between the study groups. These data suggest that the lower telomere lengths were induced earlier in infection. HCV monoinfected IDU had significantly decreased telomere lengths in their $\mathrm{CD}^{+}{ }^{+} \mathrm{T}$ cells, but $\mathrm{CD}^{+} \mathrm{T}$ cells were not affected by increased telomere erosion. Over time we observed no increase in the percentage of differentiated cells in each study group, but we did observe a continued decline of telomere erosion. Therefore it is unlikely that T-cell differentiation alone explains the continued telomere erosion. Telomere decline could be explained by increased peripheral levels of activation (HLA-DR $\left.{ }^{+} \mathrm{CD} 38^{+}\right)$, mature differentiated $\left(\mathrm{CD} 27^{-} \mathrm{CD} 57^{+}\right)$cells and exhaustion (PD-1) in peripheral $\mathrm{T}$ cells of $\mathrm{HCV}$ monoinfected and $\mathrm{HIV} / \mathrm{HCV}$ coinfected IDU which indicates a state of chronic immune activation.

As expected, we observed that telomere length decreased over time in all IDU groups. However this was independent of viral coinfections ( $\mathrm{HCV}$ or $\mathrm{HIV} / \mathrm{HCV}$ ). Interestingly, at a relatively young age the telomere length of predominantly $\mathrm{CD} 8^{+} \mathrm{T}$ cells, but also $\mathrm{CD} 4^{+} \mathrm{T}$ cells, was markedly decreased in HIV/HCV coinfected individuals and was comparable to more than 15 year older healthy donors. As most HIV/HCV coinfected individuals were cART naïve early during infection, the immune system responds to HIV with high levels of activation and proliferation rates [37]. Consequently HIV drives $\mathrm{T}$ cells to increasingly differentiated phenotypes that are oligoclonally expanded, less functional and more prone to apoptosis [38]. We demonstrated that loss of telomere length is not simply due to increased differentiation but mainly to continued immune activation. Importantly, this study demonstrates that the loss in telomere length mainly occurred at the first time-point in infection that we analysed and was not restored to the level of healthy individuals with the initiation of cART. We could not rule out that cART, via telomerase inhibition [39], negatively affects telomere length. However a recent cross-sectional study by Zanet et al. demonstrated no association between low telomere length and cART exposure [40].

Here we found that $\mathrm{HCV}$ monoinfected IDU had lower $\mathrm{CD}^{+}{ }^{+} \mathrm{T}$ cell telomere lengths than healthy donors at the first timepoint in infection that we analysed, suggesting that $\mathrm{HCV}$ on its own may have an effect on immune senescence. However, $\mathrm{CD} 8^{+} \mathrm{T}$ cell telomere length was not affected. Unfortunately we had no clinical outcomes to relate to, but a hospital-based study found that, independent of age, decreased $\mathrm{CD} 4^{+}$ 
memory telomere length was associated with increased liver fibrosis [41]. In addition, longer $\mathrm{CD}_{4}^{+}$ and $\mathrm{CD}^{+} \mathrm{T}$ cell telomere lengths were both associated with a sustained virological response following $\mathrm{HCV}$ treatment. We demonstrated that in $\mathrm{HCV}$ monoinfected IDU the decreased telomere length in $\mathrm{CD}^{+} \mathrm{T}$ cells occurred mainly in the immature $\mathrm{T}$ cells. Although this population consists of both naïve and central memory cells [42], reduced numbers of CD4 naïve $\mathrm{T}$ cells and reduced recent thymic emigrants have been associated with $\mathrm{HCV}$ infection, especially if fibrosis is present $[43,44]$. This fits with a model in which $\mathrm{CD}^{+} \mathrm{T}$ cells are continuously activated during persistent $\mathrm{HCV}$ infection, especially when the infection aggravates.. However, due to a lack of samples we were unable to investigate the specific responses of $\mathrm{HIV} / \mathrm{HCV}$ coinfected DU.

The exact mechanisms through which HIV, HCV and natural ageing collectively affect disease progression remains to be resolved. Accumulating evidence points towards a role for systemic immune senescence affecting multiple organs/tissues. Data from a recent study among IDU demonstrated that higher levels of interleukin 6, a proinflammmatory cytokine, were independently associated with $\mathrm{HCV}$ monoinfection, $\mathrm{HIV} / \mathrm{HCV}$ coinfection and increasing age [45]. Decreased telomere length has also been associated with atherosclerosis and cardiovascular disease, and is likely to be correlated with interleukin 6 levels [46].

Of interest, MEU IDU tended to have lower levels of immune activation compared to healthy donors. This special group of IDU has been shown to have detectable HIV-specific [47] and HCV-specific T-cell responses [48], indicating their exposure to both infections. The notion of a naturally occurring resistance to certain viral pathogens has major implications for T-cell vaccine development. In a recent study though, robust activation of natural killer cells, but not $\mathrm{HCV}$-specific adaptive immune responses, was associated with protection against infection with HCV among MEU DU [49].

There were several limitations in this study. Due to instability to heat we were unable to use CD45RA and CCR7 as markers of memory and differentiation in our assay. Interestingly, it did enable us to demonstrate that loss of CD27 was significantly associated with telomere loss in both $\mathrm{CD}^{+}$and $\mathrm{CD}^{+} \mathrm{T}$ cell, which occurred before the upregulation of CD57 [31].

This study is limited by the unknown duration of HIV and $\mathrm{HCV}$ infection. However, as the observed peak incidence of HIV in Amsterdam occurred during the 80's [50] we assumed that our first time point of analysis was close to the actual infection time point. For $\mathrm{HCV}$ the observed peak prevalence also occurred during the 80's. We demonstrated that the reduction in telomere length already occurred at the first time-point and that we did not find any difference in the rate of telomere length decline over a period of almost 17 years between MEU, HCV monoinfected and HIV coinfected IDU. This suggests that the telomere decline occurred earlier during infection. But, we can not rule out that the HIV or HCV infected IDU had lower telomere lengths preacquisition of HIV or HCV. To prove our hypothesis it would be of future interest to investigate telomere decline in HIV and HCV seroconverters. Unfortunately we had no access to bloodsamples of healthy donors followed over time. Because we used different healthy donors for the two time-points the decline in RTL could be biased by inter-individual variations.

\section{Conclusions}

We found increased levels of immune senescence at the first timepoint that we analysed in $\mathrm{HCV}$ mono- and $\mathrm{HIV} / \mathrm{HCV}$ coinfected DU. This suggests that HCV mono-infection and $\mathrm{HIV} / \mathrm{HCV}$ coinfection enhance T-cell immune-senescence probably early during infection. As both viruses have detrimental long-term effects on morbidity and mortality, these data express the need for early treatment, both for HCV and HIV infection.

\section{Additional files}

Additional file 1: Linear regression models of relative telomere length decline. (DOCX $14 \mathrm{~kb}$ )

Additional file 2: Flowcytometric analysis of telomere length. Example of flowcytometric analysis of telomere length by flow-FISH, where calf thymocytes (red) can be distinguished from lymphocytes (blue), not only by forward and sideward scatter (left panel) but also by the lack of CD3 expression (right panel) (A\&B). The cells were either hybridized to the peptide nucleic acid (PNA) probe (D) or underwent the same experimental conditions without the PNA probe (c) to account for the level of autofluorescence. (PDF 216 kb)

\section{Competing interests}

The authors who have taken part in this study declare they do not have anything to disclose regarding funding from industry or conflict of interest with respect to this manuscript.

\section{Authors' contributions}

BG and DB participated in the design of the study. BG and NN performed the research and analysed the data. BG was responsible for the statistical analyses. BG drafted the manuscript. DB critically revised the manuscript. All authors have read and approved the final manuscript.

\section{Acknowledgments}

The authors would like to thank all subjects for study participation; research nurses L.C. del Grande and W.M. van der Veldt for coordination, data collection and blood sampling; Dr. I. Schellens and Dr. J.A.M. Borghans for their critical appraisal on this manuscript.

\section{Funding}

This work supported by the Amsterdam Cohort Studies (ACS) on HIV infection and AIDS, a collaboration between the Amsterdam Public Health Service, the Academic Medical Center of the University of Amsterdam, Sanquin Blood Supply Foundation, and the University Medical Center Utrecht. The ACS is part of the Netherlands HIV Monitoring Foundation and 
is financially supported by the Netherlands National Institute for Public Health and the Environment. Website: http://www.amsterdamcohortstudies.org/. The funders had no role in study design, data collection and analyses, decision to publish, or preparation of the manuscript.

\section{Author details}

'Department of Research, Cluster Infectious Diseases, Public Health Service, Amsterdam, The Netherlands. ${ }^{2}$ Center for Infection and Immunity Amsterdam (CINIMA), Academic Medical Center, Amsterdam, The Netherlands. ${ }^{3}$ Department of Immunology, University Medical Center Utrecht, Utrecht, The Netherlands. ${ }^{4}$ Department of Internal Medicine, University Medical Center Utrecht, Utrecht, The Netherlands. ${ }^{5}$ Present address: Department of Immune Mechanisms, Center for Infectious Disease Control, National Institute for Public Health and the Environment (RIVM), Bilthoven, The Netherlands.

\section{Received: 17 November 2015 Accepted: 22 March 2016} Published online: 31 March 2016

\section{References}

1. Pawelec G, Effros RB, Caruso C, Remarque E, Barnett Y, Solana R. T cells and aging (update February 1999). Front Biosci. 1999:4:D216-69.

2. Lynch HE, Goldberg GL, Chidgey A, Van den Brink MR, Boyd R, Sempowski GD. Thymic involution and immune reconstitution. Trends Immunol. 2009; 30(7):366-73. doi:10.1016/j.t.2009.04.003.

3. Deeks SG. HIV infection, inflammation, immunosenescence, and aging Annu Rev Med. 2011;62:141-55. doi:10.1146/annurev-med-042909-093756.

4. Harley $C B$, Futcher $A B$, Greider CW. Telomeres shorten during ageing of human fibroblasts. Nature. 1990;345(6274):458-60. doi:10.1038/345458a0

5. Cawthon RM, Smith KR, O'Brien E, Sivatchenko A, Kerber RA. Association between telomere length in blood and mortality in people aged 60 years or older. Lancet. 2003;361(9355):393-5. doi:10.1016/S0140-6736(03)12384-7.

6. Dwyer R, Topp L, Maher L, Power R, Hellard M, Walsh N, et al. Prevalences and correlates of non-viral injecting-related injuries and diseases in a convenience sample of Australian injecting drug users. Drug Alcohol Depend. 2009;100(1-2):9-16. doi:10.1016/j.drugalcdep.2008.08.016.

7. Crofts N, Aitken CK. Incidence of bloodborne virus infection and risk behaviours in a cohort of injecting drug users in Victoria, 1990-1995. Med J Aust. 1997;167(1):17-20.

8. Memon MI, Memon MA. Hepatitis C: an epidemiological review. J Viral Hepat. 2002;9(2):84-100.

9. Vickerman P, Hickman M, May M, Kretzschmar M, Wiessing L. Can hepatitis $C$ virus prevalence be used as a measure of injection-related human immunodeficiency virus risk in populations of injecting drug users? An ecological analysis. Addiction. 2010;105(2):311-8. doi:10.1111/j. 1360-0443.2009.02759.x

10. Seeff LB. The history of the "natural history" of hepatitis C (1968-2009). Liver Int. 2009;29 Suppl 1:89-99. doi:10.1111/j.1478-3231.2008.01927.x.

11. Mathers BM, Degenhardt L, Phillips B, Wiessing L, Hickman M, Strathdee SA, et al. Global epidemiology of injecting drug use and HIV among people who inject drugs: a systematic review. Lancet. 2008;372(9651):1733-45. doi:10.1016/S0140-6736(08)61311-2.

12. Armstrong GL. Injection drug users in the United States, 1979-2002: an aging population. Arch Intern Med. 2007;167(2):166-73. doi:10.1001/ archinte.167.2.166

13. Grebely J, Dore GJ. What is killing people with hepatitis C virus infection? Semin Liver Dis. 2011;31(4):331-9. doi:10.1055/s-0031-1297922.

14. Klein RS. Trends related to aging and co-occurring disorders in HIV-infected drug users. Subst Use Misuse. 2011:46(2-3):233-44. doi:10.3109/10826084.2011.522843.

15. Salter ML, Lau B, Go VF, Mehta SH, Kirk GD. HIV infection, immune suppression, and uncontrolled viremia are associated with increased multimorbidity among aging injection drug users. Clin Infect Dis. 2011; 53(12):1256-64. doi:10.1093/cid/cir673.

16. Ferrando-Martinez S, Ruiz-Mateos E, Romero-Sanchez MC, Munoz-Fernandez MA, Viciana P, Genebat M, et al. HIV infection-related premature immunosenescence: high rates of immune exhaustion after short time of infection. Curr HIV Res. 2011;9(5):289-94.

17. Effros RB. Genetic alterations in the ageing immune system: impact on infection and cancer. Mech Ageing Dev. 2003;124(1):71-7.
18. Losina E, Schackman BR, Sadownik SN, Gebo KA, Walensky RP, Chiosi JJ, et al. Racial and sex disparities in life expectancy losses among HIV-infected persons in the united states: impact of risk behavior, late initiation, and early discontinuation of antiretroviral therapy. Clin Infect Dis. 2009;49(10):1570-8. doi:10.1086/644772

19. Antiretroviral Therapy Cohort C. Life expectancy of individuals on combination antiretroviral therapy in high-income countries: a collaborative analysis of 14 cohort studies. Lancet. 2008;372(9635):293-9. doi:10.1016/ S0140-6736(08)61113-7.

20. Jacobson IM, Cacoub P, Dal Maso L, Harrison SA, Younossi ZM. Manifestations of chronic hepatitis C virus infection beyond the liver. Clin Gastroenterol Hepatol. 2010;8(12):1017-29. doi:10.1016/j.cgh.2010.08.026.

21. Negro F. Hepatitis C, in 2013: HCV causes systemic disorders that can be cured. Nat Rev Gastroenterol Hepatol. 2014;11(2):77-8. doi:10.1038/ nrgastro.2013.222

22. Thimme R, Binder M, Bartenschlager R. Failure of innate and adaptive immune responses in controlling hepatitis $C$ virus infection. FEMS Microbiol Rev. 2012;36(3):663-83. doi:10.1111/j.1574-6976.2011.00319.x.

23. Sulkowski MS, Mehta SH, Torbenson MS, Higgins Y, Brinkley SC, de Oca RM, et al. Rapid fibrosis progression among HIV/hepatitis C virus-co-infected adults. Aids. 2007;21(16):2209-16. doi:10.1097/QAD.0b013e3282f10de9.

24. Kovacs A, Karim R, Mack WJ, Xu J, Chen Z, Operskalski E, et al. Activation of CD8 T cells predicts progression of HIV infection in women coinfected with hepatitis C virus. J Infect Dis. 2010;201(6):823-34. doi:10.1086/650997.

25. van der Helm J, Geskus R, Sabin C, Meyer L, Del Amo J, Chene G, et al. Effect of HCV infection on cause-specific mortality after HIV seroconversion, before and after 1997. Gastroenterology. 2013;144(4):751-60. doi:10.1053/j. gastro.2012.12.026. e2.

26. Aubert G, Hills M, Lansdorp PM. Telomere length measurement-caveats and a critical assessment of the available technologies and tools. Mutat Res. 2012;730(1-2):59-67. doi:10.1016/j.mrfmmm.2011.04.003.

27. Baerlocher GM, Vulto I, de Jong G, Lansdorp PM. Flow cytometry and FISH to measure the average length of telomeres (flow FISH). Nat Protoc. 2006; 1(5):2365-76. doi:10.1038/nprot.2006.263.

28. van Baarle D, Nanlohy NM, Otto S, Plunkett FJ, Fletcher JM, Akbar AN. Progressive telomere shortening of Epstein-Barr virus-specific memory $T$ cells during HIV infection: contributor to exhaustion? J infect Dis. 2008; 198(9):1353-7. doi:10.1086/592170.

29. Hoare M, Shankar A, Shah M, Rushbrook S, Gelson W, Davies S, et al. gamma-H2AX + CD8+ T lymphocytes cannot respond to IFN-alpha, IL-2 or IL-6 in chronic hepatitis C virus infection. J Hepatol. 2013;58(5):868-74. doi:10.1016/j.jhep.2012.12.009.

30. Papagno L, Spina CA, Marchant A, Salio M, Rufer N, Little S, et al. Immune activation and CD8+ T-cell differentiation towards senescence in HIV-1 infection. PLoS Biol. 2004;2(2):E20. doi:10.1371/journal.pbio.0020020.

31. Brenchley JM, Karandikar NJ, Betts MR, Ambrozak DR, Hill BJ, Crotty LE, et al. Expression of CD57 defines replicative senescence and antigen-induced apoptotic death of CD8+ T cells. Blood. 2003;101(7):2711-20. doi:10.1182/ blood-2002-07-2103.

32. Plunkett FJ, Franzese O, Finney HM, Fletcher JM, Belaramani LL, Salmon $M$, et al. The loss of telomerase activity in highly differentiated CD8 + CD28-CD27- T cells is associated with decreased Akt (Ser473) phosphorylation. J Immunol. 2007;178(12):7710-9.

33. Appay V, Papagno L, Spina CA, Hansasuta P, King A, Jones L, et al. Dynamics of T cell responses in HIV infection. J Immunol. 2002;168(7):3660-6.

34. Henson SM, Franzese O, Macaulay R, Libri V, Azevedo Rl, Kiani-Alikhan S, et al. KLRG1 signaling induces defective Akt (ser473) phosphorylation and proliferative dysfunction of highly differentiated CD8+ T cells. Blood. 2009; 113(26):6619-28. doi:10.1182/blood-2009-01-199588.

35. van den Hoek JA, Coutinho RA, van Haastrecht HJ, van Zadelhoff AW, Goudsmit J. Prevalence and risk factors of HIV infections among drug users and drug-using prostitutes in Amsterdam. Aids. 1988;2(1):55-60.

36. van den Berg CH, Grady BP, Schinkel J, van de Laar T, Molenkamp R, van Houdt R, et al. Female sex and IL28B, a synergism for spontaneous viral clearance in hepatitis C virus (HCV) seroconverters from a community-based cohort. PLoS One. 2011;6(11):e27555. doi:10.1371/ journal.pone.0027555.

37. Srinivasula S, Lempicki RA, Adelsberger JW, Huang CY, Roark J, Lee PI, et al. Differential effects of HIV viral load and CD4 count on proliferation of naive and memory CD4 and CD8 T lymphocytes. Blood. 2011;118(2):262-70. doi:10.1182/blood-2011-02-335174. 
38. Desai S, Landay A. Early immune senescence in HIV disease. Curr HIV/AIDS Rep. 2010;7(1):4-10. doi:10.1007/s11904-009-0038-4.

39. Leeansyah E, Cameron PU, Solomon A, Tennakoon S, Velayudham P, Gouillou $\mathrm{M}$, et al. Inhibition of telomerase activity by human immunodeficiency virus (HIV) nucleos(t)ide reverse transcriptase inhibitors: a potential factor contributing to HIV-associated accelerated aging. J Infect Dis. 2013;207(7):1157-65. doi:10.1093/infdis/jit006.

40. Zanet DL, Thorne A, Singer J, Maan EJ, Sattha B, Le Campion A, et al. Association between short leukocyte telomere length and HIV infection in a cohort study: No evidence of a relationship with antiretroviral therapy. Clin Infect Dis. 2014:58(9):1322-32. doi:10.1093/cid/ciu051.

41. Hoare M, Gelson WT, Das A, Fletcher JM, Davies SE, Curran MD, et al. CD4+ T-lymphocyte telomere length is related to fibrosis stage, clinical outcome and treatment response in chronic hepatitis C virus infection. J Hepatol. 2010;53(2):252-60. doi:10.1016/j.jhep.2010.03.005.

42. De Jong R, Brouwer M, Hooibrink B, Van der Pouw-Kraan T, Miedema F, Van Lier RA. The CD27- subset of peripheral blood memory CD4+ lymphocytes contains functionally differentiated $T$ lymphocytes that develop by persistent antigenic stimulation in vivo. Eur J Immunol. 1992;22(4):993-9. doi:10.1002/eji.1830220418.

43. Hartling HJ, Gaardbo JC, Ronit A, Salem M, Laye M, Clausen MR, et al. Impaired thymic output in patients with chronic hepatitis $C$ virus infection. Scand J Immunol. 2013. doi:10.1111/sji.12096.

44. Yonkers NL, Sieg S, Rodriguez B, Anthony DD. Reduced naive CD4 T cell numbers and impaired induction of CD27 in response to $T$ cell receptor stimulation reflect a state of immune activation in chronic hepatitis $C$ virus infection. J Infect Dis. 2011;203(5):635-45. doi:10.1093/infdis/jiq101.

45. Salter ML, Lau B, Mehta SH, Go VF, Leng S, Kirk GD. Correlates of elevated interleukin-6 and C-reactive protein in persons with or at high-risk for HCV and HIV infections. J Acquir Immune Defic Syndr. 2013. doi:10.1097/QAI. 0b013e3182a7ee2e.

46. Savale L, Chaouat A, Bastuji-Garin S, Marcos E, Boyer L, Maitre B, et al. Shortened telomeres in circulating leukocytes of patients with chronic obstructive pulmonary disease. Am J Respir Crit Care Med. 2009;179(7): 566-71. doi:10.1164/rccm.200809-13980C.

47. Makedonas G, Bruneau J, Lin H, Sekaly RP, Lamothe F, Bernard NF. HIV-specific CD8 T-cell activity in uninfected injection drug users is associated with maintenance of seronegativity. Aids. 2002;16(12):1595-602.

48. Ruys TA, Nanlohy NM, van den Berg CH, Hassink E, Beld M, van de Laar T, et al. HCV-specific T-cell responses in injecting drug users: evidence for previous exposure to HCV and a role for CD4+ T cells focussing on nonstructural proteins in viral clearance. J Viral Hepat. 2008;15(6):409-20. doi:10.1111/j.1365-2893.2007.00963.x.

49. Sugden PB, Cameron B, Mina M, Lloyd AR, on behalf of the Hi. Protection against hepatitis $C$ infection via NK cells in highly-exposed uninfected injecting drug users. J Hepatol. 2014. doi:10.1016/j.jhep.2014.05.013.

50. de Vos AS, van der Helm JJ, Matser A, Prins M, Kretzschmar ME. Decline in incidence of HIV and hepatitis C virus infection among injecting drug users in Amsterdam; evidence for harm reduction? Addiction. 2013;108(6):1070-81. doi:10.1111/add.12125.

\section{Submit your next manuscript to BioMed Central and we will help you at every step:}

- We accept pre-submission inquiries

- Our selector tool helps you to find the most relevant journal

- We provide round the clock customer support

- Convenient online submission

- Thorough peer review

- Inclusion in PubMed and all major indexing services

- Maximum visibility for your research

Submit your manuscript at www.biomedcentral.com/submit

C Biomed Central 